\title{
Sócrates por Xenofonte: a filosofia em ação para a construção de um homem integralmente forte e senhor de si mesmo
}

\author{
Aldo Lopes Dinucci \\ Universidade Federal de Sergipe \\ aldodinucci@yahoo.com.br
}

\begin{abstract}
Xenophon's Socrates, by making a distinction between things that are under our control and things that are not, decides that thought should occupies itself only with human things, in order that the individual can achieve a degree of freedom that allows him to be a good friend, an exemplar warrior and politician, so that his soul can become good, beautiful and noble through self-knowledge.

KEYWORDS: ethics; Xenophon; socratism; classical philosophy.
\end{abstract}

\section{Introdução}

Xenofonte é dono de um estilo de escrita coloquial e vívido, quase jornalístico, que sempre encantou seus leitores, pelo que foi considerado, na Antigüidade, o verdadeiro porta-voz do pensamento socrático. Um militar por profissão, membro da classe dos cavaleiros, era também amigo de Antístenes, discípulo extremado de Sócrates. Consideramos, entretanto, um truísmo afirmar que a versão de Xenofonte do pensamento de Sócrates é muito influenciada por este precursor do cinismo. Defendemos uma outra leitura para a construção do Sócrates de Xenofonte.

Narram os textos que, durante a restauração da democracia em Atenas, percebendo o círculo fechar-se sobre si e os demais socráticos, Xenofonte teria perguntado a Sócrates se deveria ou não ingressar nas forças gregas reunidas para auxiliar Ciro em seu esforço de guerra civil; Sócrates respondeu-lhe que indagasse ao oráculo de Delfos quanto a isso. ${ }^{1}$ Porém, para a irritação de Sócrates, Xenofonte fez outra pergunta ao oráculo, que pode ser relatada assim: para quais deuses deveria oferecer sacrifícios, a fim de que sua expedição fosse um sucesso? Ora, em nosso ponto de vista, esse evento mostra uma característica da personalidade de um autor que acaba por transparecer, claramente, na versão escrita dos atos e pensamento de Sócrates: personagem e narrador tornam-se um indivíduo totalmente voltado para a ação, a tal ponto que sequer se concebe a alternativa, diante do perigo iminente em Atenas, de não

\footnotetext{
${ }^{1}$ Cf. Memoráveis 3. 1.
} 
ingressar na expedição militar. Para Xenofonte, é impossível não agir: daí, como veremos à frente, o pensamento socrático de Xenofonte ser um "pensamento em ação". O Sócrates de Xenofonte, como aquele dos primeiros diálogos de Platão, ${ }^{2}$ põe de lado as investigações de caráter especulativo e volta o pensamento todo para a prâxis individual, de modo que a sua filosofia passa a ser a arte de bem viver e da busca pela sabedoria de vida. O Sócrates de Xenofonte é totalmente voltado para questões práticoexistenciais como a amizade, o cuidado com o corpo, a paz, a guerra, a servidão e a liberdade.

Buscando realizar uma síntese do pensamento do filósofo ateniense em Xenofonte, mapeando-o e descrevendo-o, tratarei a seguir dos seguintes temas: (1) a piedade, o daimónion e o uso de oráculos; (2) as coisas humanas, a prudência e o domínio de si; (3) o cuidado com o corpo e a frugalidade; (4) o despojamento; (5) a liberalidade, a generosidade e a amizade; (6) o éros socrático, (7) a sabedoria humana; (8) o direito do mais forte e (9) éros e a busca pela sabedoria.

\section{A piedade, o daimónion e o uso de oráculos}

Segundo Xenofonte, ${ }^{3}$ Sócrates oferecia sacrifícios em casa e nos templos públicos. O modelo de conduta coincide, em parte, com o de Xenofonte, que praticava ele mesmo sacrifícios, tendo-se tornado, na velhice, sacerdote de Ártemis Caçadora e dedicado a essa deusa um templo e um campo de caça. ${ }^{4}$ Segundo esse paradigma de “piedade", Sócrates teria aceitado a regra que se tornou proverbial na Antigüidade 5 através de Hesíodo, ${ }^{6}$ julgando-a a boa interpretação para o oráculo délfico, que dissera ser "seguir o costume da pólis" (nómoi poléos) o modo correto de "dar graças (charízesthai) aos deuses".

\footnotetext{
${ }^{2}$ São eles: Apologia, Cármides, Críton, Eutífron, Eutidemo, Górgias, Hípias Menor, Íon, Lísias, Laques, Protágoras, Livro I da República e primeira parte do Mênon. São diálogos supostamente depositários do pensamento do Sócrates histórico, que se caracterizaria, entre outras coisas, por seu caráter aporético e exclusivamente ético, isento das chamadas teorias platônicas, como a tese do mundo das Idéias, a da imortalidade da alma e a da reminiscência.

${ }^{3}$ Cf. Memoráveis I 1, 2; Apologia 10-12.

${ }^{4}$ Cf. Anábasis 5, 3.

${ }^{5}$ Cf. Memoráveis I 3, 3; IV 3, 16.

${ }^{6}$ Cf. Os trabalhos e os dias 336: "Oferecer sacrifícios segundo suas próprias posses". As traduções de Hesíodo para Os trabalhos e os dias utilizadas nesse artigo são de autoria de Ana Elias Pinheiro e José Ribeiro Ferreira.

${ }^{7}$ Cf. Memoráveis IV 3, 16-17.
} 


\section{nuntius antiquus}

Xenofonte refere-se também ao daimónion socrático. Nos Memoráveis, ${ }^{8}$ é dito que, enquanto os demais viam nos pássaros e nos demais augúrios signos divinos, para Sócrates era o daimónion que significa (tò daimónion gàr éphe semaínein). Esse daimónion transmitiria conselhos não somente a Sócrates, mas também a seus amigos. ${ }^{9}$

Quanto aos oráculos, o Sócrates de Xenofonte raciocina a partir das seguintes premissas: (a) os deuses são benéficos para os homens, (b) os deuses são oniscientes (tendo acesso inclusive a tudo o que se passa em nossas almas) e onipresentes, (c) conferindo aos homens signos para guiá-los em seus assuntos quando necessário. ${ }^{10}$ Tal crença de Sócrates nos oráculos refuta, para Xenofonte, a acusação de ateísmo que fora feita contra seu mestre, ${ }^{11}$ e determina, como veremos a seguir, os rumos da própria filosofia socrática:

Outro modo que ele < Sócrates $>$ tinha ao lidar com os amigos íntimos era este: se não houvesse espaço para dúvida, ele os aconselhava a agir do modo que eles consideravam o melhor; mas, se as conseqüências não pudessem ser previstas, ele os enviava ao oráculo para indagar se a coisa devia ser feita. ${ }^{12}$

Assim, a regra de Sócrates para o uso de oráculos seria a seguinte: as questões que podem ser respondidas com o auxílio das artes humanas devem ser resolvidas sem auxílio divino; mas as questões que extrapolam essas artes devem ser solucionadas com o auxílio de oráculos e meios análogos, sendo sinal de impiedade tanto indagar aos deuses o que se pode saber pelas artes quanto tentar responder sem auxílio divino questões que estão fora do alcance dessas mesmas artes. ${ }^{13}$ Sócrates, assim, realiza uma distinção entre o que depende e o que não depende dos homens e compromete seu pensamento com as coisas humanas (t'anthrópina), ou seja, com os assuntos e questões cujas soluções dependam unicamente das artes humanas.

\section{As coisas humanas, a prudência e o domínio de si}

\footnotetext{
${ }^{8}$ Cf. Memoráveis I 1, 3-4.

${ }^{9}$ Cf. Memoráveis 1, 4-5; IV 8, 5; Apologia 13.

${ }^{10} \mathrm{Cf}$. Memoráveis I 1, 19; IV 3, 2; Ciropédia I 4, 46.

${ }^{11}$ Cf. Memoráveis I 1, 5-6.

${ }^{12}$ Cf. Memoráveis I 1, 6. As traduções de Xenofonte para os Memoráveis de Sócrates utilizadas nesse artigo são de autoria de E. C. Marchant, vertidas por mim para o português.

${ }^{13}$ Cf. Memoráveis I 1, 7-9.
} 


\section{nuntius antiquus}

$\mathrm{Na}$ medida em que se ocupa somente das coisas relativas ao homem, Sócrates põe de lado as questões da filosofia da natureza, ${ }^{14}$ argumentando ser loucura tanto ocupar-se desses assuntos sem um conhecimento completo das coisas humanas, quanto negligenciar o conhecimento dessas em nome do conhecimento das divinas:

Suas conversas - diz-nos Xenofonte ${ }^{15}$ - eram sempre sobre as coisas humanas. Os problemas que ele discutia eram o que é o pio, o que é o ímpio; o que é o belo, o que é o feio; o que é o justo, o que é o injusto; o que é a prudência, o que é a loucura [...]. Esses e outros como esses, conhecimentos que, pensava ele, tornam o homem bom e belo (kalós kaì agathós), enquanto os que ignoram tais coisas com justiça são chamados prisioneiros.

A palavra "prisioneiros" traduz andrápodon, ${ }^{16}$ termo grego aplicado aos cativos de guerra que, recém-escravizados, chegavam à cidade com os pés e as mãos acorrentados. Assim, não dispor do conhecimento das coisas humanas, que se busca através do diálogo com aqueles com os quais temos afinidade, ${ }^{17}$ é escravidão no pior sentido do termo, fica-se impedido de caminhar e agir... Por outro lado, adquirir tal conhecimento e tornar-se kalòs kaì agathós significa também adquirir a antiga virtude (archaîa areté) dos ancestrais, com a qual esses venceram os obstáculos da vida. ${ }^{18}$ Os antigos exemplos de virtude devem guiar e inspirar os homens em sua busca pela areté $^{19}$ e essa prática leva à constatação do grau de degeneração dos costumes. ${ }^{20}$

Para evitar que o homem use o pensamento para corromper os costumes (por exemplo, criando argumentos que justifiquem o vício), é preciso, antes, enveredar pelo caminho da razão crítica, educá-lo para a "prudência" (sophrosýne). ${ }^{21}$ Essa, por sua vez, é atingida através do império sobre si mesmo ou do autodomínio (enkráteia). O próprio Sócrates é descrito por Xenofonte como senhor absoluto de si mesmo:

Controlando seus desejos sensuais e apetites, tinha o maior autodomínio entre todos os homens. Além disso, suportando frio e calor e todo tipo de labor, era o mais perseverante; e suas necessidades eram tão moderadas que ele se contentava com bem pouco. ${ }^{22}$

\footnotetext{
${ }^{14}$ Cf. Memoráveis I 1, 11.

${ }^{15}$ Cf. Memoráveis I 1, 16.

${ }^{16} \mathrm{O}$ termo doûlos, por outro lado, se refere ao escravo em geral.

${ }^{17}$ Cf. Memoráveis VI 5, 12.

${ }^{18} \mathrm{Cf}$. Memoráveis III 5, 8.

${ }^{19}$ Cf. Memoráveis III 5, 9.

${ }^{20} \mathrm{Cf}$. Memoráveis III 5, 1ss.

${ }^{21}$ Cf. Memoráveis IV 3, 1; IV 5, 1.

${ }^{22}$ Cf. Memoráveis I 2, 1-3.
} 
Xenofonte afirma que Sócrates extirpara de vários homens vícios como a impiedade e a luxúria, fazendo-os ver que, através da autodisciplina, obteriam a kalokagathía, não ensinada por ele próprio, mas inspirada em seus amigos através de seu bom exemplo. ${ }^{23}$ A exemplar kalokagathía socrática se manifestava pela prudência do próprio Sócrates, engendrada pela enkráteia que se desdobrava no domínio das paixões sensuais e dos apetites, no despojamento e no fortalecimento físico através da resistência ao frio e ao calor.

\section{O cuidado com o corpo a a frugalidade}

Estimulando o fortalecimento do corpo através de exercícios físicos e da conquista de bons hábitos, ${ }^{24}$ aprimora-se não somente o corpo, mas também a alma, pois, através dessa práxis filosófica, conquista-se progressivamente a liberdade (eleuthería), ${ }^{25}$ já que o homem passa a depender cada vez menos de seu entorno, habituando-se a comer o que houver, a ser capaz de resistir a condições físicas adversas, e tornando também, por essa mesma razão, a vida mais fácil para si. ${ }^{26}$

A liberdade decorrente da prudência e do autodomínio se contrapõe à servidão da incontinência, pois o incontinente é escravo de suas paixões. ${ }^{27} \mathrm{O}$ glutão, por exemplo, não come por prazer, mas por compulsão, e o mesmo vale para todos os vícios, pois em todos os casos de vício o ser humano se vê compelido a fazer algo que a princípio fez por prazer.

Sócrates considera que a educação tem seu princípio justamente com a alimentação, pois o homem começa a regular seu comportamento e a adquirir poder sobre si mesmo na medida em que controla seus apetites. ${ }^{28}$ Xenofonte afirma ${ }^{29}$ que a regra de Sócrates a respeito da alimentação é comer o suficiente para garantir o prazer de comer, e isso se dá quando "se faz da fome o melhor tempero", e o mesmo vale para o beber. Deve-se comer e beber tão somente quando se tem fome e sede, e apenas até ficar saciado. Sócrates ilustra esse princípio com uma história de Ulisses e seus

\footnotetext{
${ }^{23}$ Cf. Memoráveis I 3-4.

${ }^{24}$ Cf. Memoráveis I 2, 4-5; Ciropédia I, VI 17.

${ }^{25}$ Cf. Memoráveis I 2, 6.

${ }^{26} \mathrm{Cf}$. Memoráveis I 3, 5.

${ }^{27}$ Cf. Memoráveis IV 5, 3-4.

${ }^{28}$ Cf. Memoráveis II 1, 5.

${ }^{29}$ Cf. Memoráveis I 3, 5-8; Ciropédia I 5, 12; Banquete IV 40-42.
} 
companheiros: $:^{30}$ quando chegam à ilha de Circe, todos, com exceção de Ulisses, se banqueteiam fartamente, e todos são transformados em porcos por ela, salvo Ulisses, o qual, tanto por seguir o conselho de Hermes quanto por sua frugalidade, havia evitado participar da comilança.

Além disso, o filósofo critica claramente os banquetes atenienses, afirmando que os alimentos neles servidos são extravagantes e arruínam o corpo por sua excessiva preparação, o que indica que, para Sócrates, os melhores alimentos são os consumimos in natura ou com um mínimo de preparo. ${ }^{31}$ Assim, bem comer significa comer algo que não faça mal nem ao corpo nem à alma e se encontre com facilidade. Comer com autodomínio propicia tanto o prazer na alimentação quanto a saúde do corpo e a liberdade da alma. O homem que belamente se dispõe (diaitómenos kósmios) tem de saber bem comer (euochê̂sthai) e, conseqüentemente, ser frugal. ${ }^{32}$

A prática da prudência em relação aos apetites da mesa é estendida aos apetites da carne. Sócrates aconselha evitar as paixões amorosas enquanto não se dispuser de autodomínio, pois vê na entrega aos desejos sensuais a razão da escravidão de muitos. Apenas quem tem pleno autodomínio pode-se dar a provar os frutos da carne e, ainda assim, seguindo a mesma regra da alimentação: servir-se das coisas de Afrodite

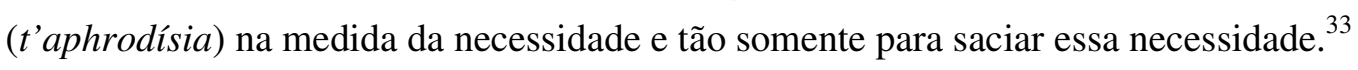

\section{O despojamento}

Quanto aos bens materiais, a prescrição socrática é tê-los na medida exata do uso, desaconselhando, para se garantir a liberdade, a pretensão no vestir-se e o amor pelo dinheiro. ${ }^{34}$ Sócrates é representado por Xenofonte a defender essas idéias diante do sofista Antífon, o qual, deplorando o modus vivendi socrático, declara que, por meio desse procedimento, alcança-se, de fato, uma vida intolerável mesmo para um escravo. Criticando o fato de Sócrates não cobrar taxas pelo seu ensino de filosofia e vestir-se com um único e miserável manto, jamais usando sandálias e túnicas, ${ }^{35}$ Antífon rejeita, contundentemente, a prática socrática. Sócrates responde a ele que não cobra taxas justamente para garantir sua própria liberdade, e para não ter de falar com alguém só

\footnotetext{
${ }^{30}$ Cf. Odisséia X 281 ss.

${ }^{31}$ Cf. Memoráveis III 14, 5-6.

${ }^{32} \mathrm{Cf}$. Memoráveis III 14, 7.

${ }^{33}$ Cf. Memoráveis I 3,14-15.

${ }^{34} \mathrm{Cf}$. Memoráveis I 2, 4 ss.

${ }^{35}$ Cf. Memoráveis I 4,1-3.
} 
porque esse o paga. ${ }^{36}$ Quanto ao manto e às sandálias, Sócrates responde que sua função é proteger o corpo, o que seu manto velho faz muito bem, e, se não necessita de sandálias, é porque se exercitou para andar descalço. O treinamento físico é melhor que sua ausência, na medida em que fortalece o corpo e torna o homem mais independente. Assim, conclui o mestre: evitar tornar-se escravo do estômago, do sono, da incontinência e de confortos garante prazeres outros e mais elevados, advindos do autodomínio; inclui-se entre eles, sobretudo, a satisfação de ver-se progredindo para a kalokagathía e - ponto fundamental que começaremos a seguir a considerar em detalhes - adquirir amigos melhores. ${ }^{37}$ Essa temática é retomada no Banquete de Xenofonte: nele, Antístenes ensina-nos que a riqueza está não nas propriedades, mas no coração dos homens, pois o ganancioso é sempre pobre, não importando o quanto possua, já que a ganância sempre o faz descontente com suas posses. ${ }^{38}$ Essa ganância é a razão de roubos, tráfico de escravos e assassinato em massa. ${ }^{39}$ Antístenes, porém, declara-se rico por possuir comida e bebida suficientes para saciar-se, roupas suficientes para protegerse do frio, uma cama boa o suficiente para fazê-lo despertar com facilidade ao amanhecer, além de o satisfazerem plenamente mulheres pouco atraentes para outros. Tudo isso, diz-nos Antístenes ao final de seu discurso no Banquete, ${ }^{40}$ fá-lo ter tempo livre (scholé); mas a desvantagem que sobrevém para os que amam o luxo e o dinheiro é serem sempre ocupados com banalidades e sem tempo para si mesmos.

\section{A liberalidade, a generosidade e a amizade}

Antístenes observa também ${ }^{41}$ que a inclinação para o despojamento torna mais justo (dikaiotéros) o homem do que o amor pelo dinheiro, pois essa paixão o faz desejar o alheio, ao contrário do despojamento, que torna o homem "generoso". "Generoso" traduz eleuthérous que no âmbito socrático, significa não somente aquele que possui liberdade de ação, mas também, e principalmente, aquele que não é escravo dos apetites, bens materiais e falsas opiniões. Há, porém, outro sentido para eleútheros, que é o da "franqueza, honestidade, liberalidade, nobreza, generosidade". Podemos sem receio associar todas essas qualidades à kalokagathía socrática.

\footnotetext{
${ }^{36}$ Cf. Memoráveis I 4, 4.

${ }^{37} \mathrm{Cf}$. Memoráveis I 4, 6-9.

${ }^{38} \mathrm{Cf}$. Banquete IV 34.

${ }^{39} \mathrm{Cf}$. Banquete IV 35-36.

${ }^{40}$ Cf. Banquete IV 43-44.

${ }^{41} \mathrm{Cf}$. Banquete IV 41-43.

${ }^{42} \mathrm{Cf}$. Banquete IV 43.
} 


\section{nuntius antiquus}

Sobretudo a liberalidade e a generosidade nos interessam neste momento, pois começamos a compreender que, para o Sócrates de Xenofonte, a conquista da frugalidade e do despojamento leva não somente ao autodomínio e à liberdade, mas também à amizade. Com efeito, como um homem ganancioso e mesquinho pode ser um bom amigo? Como um homem incapaz de compartilhar e que dá valor em primeiro lugar aos apetites e aos bens pode predispor-se à busca da amizade por ela mesma?

Para Sócrates, o objetivo fundamental da prática filosófica é justamente adquirir bons amigos, declarando ser a "arte de caçar amigos" (phílous therásein) a mais nobre entre todas, caçada que se faz não com cães, mas com pessoas capazes de perceber, pelo olhar, um amante da beleza (philókalos). Dessa forma, diante de tal pessoa, carece serlhe doce nas palavras, visitá-la quando doente, felicitá-la na boa fortuna, dispor-se a servi-la. Um amigo sincero é, para Sócrates, o bem mais precioso que se pode obter. ${ }^{43}$ Em decorrência disso, o filósofo critica os homens de sua época por terem em tão pouca conta a amizade e darem mais importância aos negócios e aos escravos que à aquisição de amigos, além de nem saberem dizer ao certo quais são os seus amigos. ${ }^{44} \mathrm{Um}$ amigo, porém, não pode ser obtido nem mantido pela violência, mas pela brandura e pela doçura, através da retribuição de favores, da generosidade e da sinceridade. Tais são "as poções e os encantamentos" pelos quais se conquistam as amizades, 45 "poções" que Sócrates estuda com seus amigos. ${ }^{46}$ Ou seja, essa generosidade, essa doçura, esse cuidado, esse amor pelo belo, essa sinceridade, tudo isso é, enquanto fruto da kalokagathía, engendrado pela filosofia. Sem essa, simplesmente não podemos ser bons amigos e, consequientemente, ter bons amigos, ${ }^{47}$ pois o filosofar leva o homem a amar o que é bom e belo na mesma medida em que torna ele mesmo bom e belo para ser amado.

Assim, Sócrates diz amar aqueles que se destacavam em excelência e bondade, ${ }^{48}$ e Antístenes diz, no Banquete (VIII 3-4), amar enormemente a Sócrates. Ainda no Banquete (II 4), Sócrates afirma ser a kalokagathía o aroma que se obtém quando

\footnotetext{
${ }^{43}$ Cf. Memoráveis II 4, 1.

${ }^{44}$ Cf. Memoráveis II 4, 2 ss.

${ }^{45}$ Cf. Memoráveis III 11, 6ss.; II 6, 10ss.

${ }^{46}$ Cf. Memoráveis III 16.

${ }^{47}$ Cf. Memoráveis II 5. Correlativamente, uma série de defeitos oriundos da negligência em relação à kalokagathía (como a glutonaria, a bebedeira, a lubricidade, a indolência, o amor pelo dinheiro - cf. Memoráveis II 6, 1ss.) são capazes de fechar as portas para a amizade.

${ }^{48}$ Cf. Memoráveis IV, I, 1.
} 
pessoas que se dedicam à prática da excelência se encontram e passam a conviver. ${ }^{49}$ Tudo isso porque a alma, na medida em que se torna mais sábia (phronimóteron), tornase mais digna de ser amada (axierastotéra) e mais adorável. ${ }^{50}$

\section{6. Éros socrático}

No Banquete de Xenofonte, como no de Platão, Sócrates desenvolve uma teoria sobre esse amor da amizade, que ele cuidadosamente distingue do amor carnal. Diante da já mencionada declaração de amor de Antístenes a Sócrates, ele recomenda ironicamente que se guarde esse amor como segredo, já que o amor não é por sua alma, mas por seu belo corpo. ${ }^{51}$ Sócrates então distingue entre duas fontes de amor. Com a ressalva de não saber ao certo se há realmente duas Afrodites, uma celeste (Aphrodíte Ouránia) e outra terrena, ou vulgar (Aphrodíte Pandémos), o filósofo reconhece que há dois cultos para a deusa, um para cada tipo de Afrodite, sendo licenciosos os rituais da comum, e puros os da celeste. ${ }^{52}$ Conclui daí a existência de dois tipos de amor (éros), um dos corpos e outro da alma, da amizade e das belas ações (tês psychês te kaì tês philías kaì tôn kalôn érgon). ${ }^{53}$

Sócrates, em seguida, afirma a superioridade do éros celeste sobre o vulgar. ${ }^{54}$ Em primeiro lugar, porque a verdadeira comunidade (synousía) pressupõe a amizade, além de que os que se unem por laços de amizade têm sempre gosto por essa união, enquanto muitos dos que se ligam carnalmente odeiam ver-se unidos. Em segundo lugar, porque a amizade tende a durar mais do que a atração carnal: o viço da juventude logo se vai, enquanto a alma se torna mais digna de ser amada na medida em que cresce em sabedoria. ${ }^{55}$ Em terceiro lugar, porque o amor carnal logo alcança a saciedade, o que não se dá com o amor da alma, por ser puro (agné). Porém, nem por isso o amor da alma é desprovido das graças de Afrodite, muito pelo contrário: o prazer de se olhar a face do amigo, as conversas íntimas, a confiança recíproca, o cuidado mútuo, a alegria

\footnotetext{
${ }^{49} \mathrm{O}$ homem, porém, que se liga aos maus, corrompe-se e afasta-se da kalokagathía, como nos indica a mesma passagem do Banquete.

${ }^{50} \mathrm{Cf}$. Memoráveis VIII 14-15.

${ }^{51}$ Cf. Memoráveis VIII 6-7.

${ }^{52}$ Cf. Memoráveis VIII 8-10.

${ }^{53}$ Cf. Memoráveis VIII 10.

${ }^{54} \mathrm{Cf}$. Memoráveis VIII 12ss.

${ }^{55}$ Cf. Memoráveis VIII 13-15.
} 
comum na prosperidade, o apoio durante os infortúnios, todas essas coisas ${ }^{56}$ estão cheias dos dons de Afrodite (epaphródita). ${ }^{57}$

Além tudo isso, quem se vê tomado pelo éros vulgar tem uma relação muito distinta com o ser amado diante daquele que se vê envolvido pelo éros celeste, pois o primeiro é como quem alugou uma fazenda e nada quer senão extrair o máximo das terras, enquanto o segundo, que busca a amizade, é como quem possui uma fazenda: não se limita a extrair os frutos da terra, mas busca valorizá-la. Em outras palavras, aquele que ama com o amor vulgar toma o outro como coisa da qual se apoderou e serve-se dele até a exaustão, enquanto aquele que ama como amigo não tem em vista o seu próprio benefício, mas busca ajudar seu amigo de todas as maneiras possíveis.

\section{A humana sabedoria}

Analisemos agora outras características da sabedoria que se obtém através desse exercício filosófico. Sócrates primeiramente a identifica com o conhecimento (epistéme ára sophía estín), ${ }^{58}$ observando que a nenhum homem é possível um conhecimento de todas as coisas (tà ónta pánta epístasthai) e, assim, cada um é sábio tão somente na medida de seu saber (hò ára epístatai hekástos, toûto kaì sophós estín). O bem (agathós), por outro lado, é aquilo que é útil (agathón eînai e tò ophélimon), ${ }^{59}$ e o belo (kalós) assim o será pelo mesmo motivo. ${ }^{60}$ Logo, o raciocínio indica que só pode agir de modo bom e belo aquele que souber a utilidade do objeto sobre o qual agirá.

Sócrates exemplifica seu raciocínio com o caso da coragem, ${ }^{61}$ que é bela e útil, e com a qual se age de modo igualmente belo e útil. Quem não teme as coisas que devem ser temidas não é verdadeiramente corajoso: sua ignorância implica somente temeridade. E, da mesma forma, quem teme as coisas que não devem ser temidas é, por sua ignorância, covarde. Assim, para ser bom, belo e corajoso diante das coisas, insta saber lidar com elas, distinguindo com correção o que deve e o que não deve ser temido. Portanto, a sabedoria própria do homem é aquela que, partindo do reconhecimento de que nenhum homem jamais terá uma sabedoria de tudo ou do reconhecimento das limitações próprias da condição humana, indica a real utilidade das coisas, o modo

\footnotetext{
${ }^{56}$ Cf. Memoráveis VIII 23-26.

${ }^{57}$ Cf. Memoráveis VIII 15-18.

${ }^{58}$ Cf. Memoráveis IV 6, 7.

${ }^{59}$ Cf. Memoráveis IV, 6, 8ss.

${ }^{60} \mathrm{Cf}$. Memoráveis IV 6, 9.

${ }^{61}$ Cf. Memoráveis IV 6, 10-11.
} 
correto de lidar com acontecimentos, pessoas e o que mais houver relativo aos homens, propiciando a ação bela e boa. Dessa forma, Sócrates considera-a como sinônimo de prudência e, complementarmente, sábio aquele que conhece e pratica o que é belo e bom e evita o que é mau. ${ }^{62}$ Como conseqüência disso tudo, toda excelência será sabedoria:

Ações justas e toda forma de atividade virtuosa são belas e boas. Aquele que conhece o belo e o bom nunca escolherá uma outra coisa, aquele que os ignora não pode realizá-los e, mesmo se tentar, falhará. Logo, o sábio faz o que é belo e bom, o não sábio não pode fazê-lo, e, se o tentar, fracassará. Por essa razão, já que as ações justas e todas as outras formas de atividade bela e boa são ações virtuosas, é evidente que a justiça, e toda outra forma de virtude, é sabedoria. ${ }^{63}$

A passagem acima evidencia também um princípio socrático que vemos nos diálogos da juventude de Platão: o conhecimento do que é bom e belo determina a ação virtuosa, o desconhecimento determina o contrário. Em outros termos, a causa do erro será a ignorância. Essa ignorância, entretanto, não é identificada com a loucura (manía), que Sócrates diz ser o contrário da sabedoria: ${ }^{64}$ no extremo oposto da sabedoria temos o completo desconhecimento de si mesmo e pensar saber o que verdadeiramente não se sabe. Por essa razão, o filósofo demonstra aos que se crêem possuidores da melhor educação, sábios e donos da verdade, que realmente não sabem o que pensam saber. Xenofonte exemplifica a argumentação com o caso de Eutidemo, que, por ter uma grande biblioteca, se cria um prodígio de sabedoria. ${ }^{65}$

Justamente com Eutidemo, Sócrates desenvolve o tema do "conhece-te a ti mesmo". Indagado quanto a isso, Eutidemo afirma ser esse seu primeiro saber, pois diz ele ${ }^{66}$ - como poderia conhecer algo se não conhecesse antes a si mesmo? Sócrates, em seguida, avalia com Eutidemo o que significa propriamente conhecer-se. Chegam à conclusão que isso equivale a conhecer as próprias capacidades (dynámeis): ${ }^{67}$ aquele que se conhece sabe quais coisas lhe são convenientes, além de suas próprias qualidades e limitações. Tal homem prospera buscando o que precisa e o que pode alcançar, não

\footnotetext{
${ }^{62}$ Cf. Memoráveis III 9, 4.

${ }^{63}$ Cf. Memoráveis III 9, 5.

${ }^{64} \mathrm{Cf}$. Memoráveis III 9, 6.

${ }^{65} \mathrm{Cf}$. Memoráveis IV 2, 1 ss.

${ }^{66} \mathrm{Cf}$. Memoráveis IV 2, 24.

${ }^{67}$ Cf. Memoráveis IV 2, 25.
} 
tentando fazer algo acima de suas forças. ${ }^{68}$ Quem não dispõe desse conhecimento engana-se ao avaliar suas capacidades e no trato com outros homens e assuntos, não sabendo o que quer, nem o que fazer, nem com quem conviver, ${ }^{69}$ fracassando e sendo imediatamente punido através do próprio fracasso, tornando-se ridículo, indigno e sendo humilhado. ${ }^{70} \mathrm{O}$ mesmo acontece com os povos: os que ignoram suas capacidades entram em conflito com nações mais fortes, sendo exterminados ou escravizados. ${ }^{71}$

A prudência, que se obtém primeiramente a partir do império sobre si mesmo em relação ao comer, ao vestir-se, aos bens materiais, bem como a partir de exercícios físicos que fortaleçam o sentido de independência no indivíduo, é cultivada através do conhecimento da utilidade das coisas relativas ao homem, do questionamento e do conhecimento de si mesmo. Essa prudência é a sabedoria humana que se busca, com a qual todas as demais coisas tornam-se bens para o homem. Além disso, o homem prudente será o mais apto a governar, ${ }^{72}$ pois governa em primeiro lugar a si mesmo, suas paixões e seus apetites e sabe como lidar com os homens e seus assuntos. ${ }^{73}$ Pelas mesmas razões, será um guerreiro excelente, senhor de si e capaz de resistir à fome e ao frio, temendo o que deve ser temido e sendo corajoso diante do que não é verdadeiramente temível.

\section{O direito do mais forte}

Um questionamento é introduzido nos Memoráveis, ${ }^{74}$ colocando em xeque todo o discurso de Sócrates em favor da conquista da sabedoria: não haveria uma via intermediária entre a escravidão e a liberdade, pela qual se pudesse usufruir a vida sem ter de passar pela dura educação que leva à prudência e à kalokagathía? Sócrates responde a isso deste modo:

Mas, se essa via não conduz nem ao mando nem à escravidão, poderias igualmente dizer que nem aos homens. Se, em todo caso, entre os homens crês estar essa via, e não julgas conveniente nem governar nem ser governado, nem servirás espontaneamente aos que

\footnotetext{
${ }^{68}$ Cf. Memoráveis IV 2, 26.

${ }^{69}$ Cf. Memoráveis IV 2, 27.

${ }^{70}$ Cf. Memoráveis IV 2, 29.

${ }^{71}$ Cf. Memoráveis IV 2, 29.

${ }^{72}$ A excelência política supõe a prudência, mas o contrário não é verdadeiro, pode-se possuir a kalokagathía e não a capacidade para comandar. Portanto, antes de ingressar na política, é preciso saber se se possui ou não esta capacidade. O mesmo vale para o generalato (cf. Memoráveis IV 2, 11).

${ }^{73}$ Cf. Memoráveis II 1, 1ss.

${ }^{74}$ Cf. Memoráveis II 1, 11.
} 


\section{nuntius antiquus}

governam, penso que deves ver que os mais fortes têm o hábito de usar como escravos os mais fracos, determinando os queixosos tanto na vida pública quanto na vida privada. Ou te passam despercebidos os que cortam o trigo e as árvores daqueles que enrolam o trigo em espirais e plantam árvores, atormentando de todas as maneiras os mais fracos que não desejam servir, até que esses se convençam a escolher serem escravos ao invés de fazer guerra aos mais fortes? Pois não sabes que também na vida particular os corajosos e os poderosos arrebatam os covardes e os impotentes, que são então escravizados? ${ }^{75}$

Aqui se evidencia o sentido final do pensamento socrático em Xenofonte: o direito do mais forte é afirmado como princípio normativo da sociedade humana. A busca pela sabedoria, pela prudência, pelo império sobre si mesmo se faz em nome da liberdade (eleuthería). Sem isso, o homem é escravizado, seja na vida privada, seja na vida pública. Justifica-se assim a árdua busca pela sabedoria: essa busca objetiva não somente tornar o homem senhor de si mesmo, bom e belo em suas ações, mas, sobretudo, forte diante dos outros homens e do mundo. Os famosos versos de Hesíodo do poema $O$ trabalho e os dias são evocados ${ }^{76}$ para fundamentar essa tese:

Facilmente e em abundância se podem obter as coisas vis [...] Mas antes da virtude os deuses imortais colocaram o suor: longo e penoso é o caminho para ela, e duro a princípio; mas, quando alcanças o topo, então [...] a via, difícil que era antes, se torna fácil. ${ }^{77}$

O testemunho de Epicarmo também é chamado através de seu verso que diz: "Os deuses nos vendem todos os bens ao preço do sofrimento", 78

\section{9. Éros e a busca pela sabedoria}

Façamos por fim um questionamento, nesse esforço de síntese do pensamento de Sócrates em Xenofonte: se a sabedoria é conhecimento, como pode o ignorante partir em sua busca? Como alguém pode fazer a escolha pela sabedoria não dispondo ainda de conhecimento algum? Sócrates ensaia uma resposta a isso nos Memoráveis quando nos afirma:

Penso que todos os homens têm uma escolha entre vários cursos de ação, e escolhem e seguem aquele que eles pensam conduzir

\footnotetext{
${ }^{75}$ Cf. Memoráveis II 1, 11.

${ }^{76} \mathrm{Cf}$. Memoráveis II 1, 20.

${ }^{77}$ Cf. Os trabalhos e os dias, v. 285-295.

${ }^{78}$ Fragmento DK 36. Esse fragmento ocorre apenas em Xenofonte (Memoráveis II 1, 20).
} 


\section{nuntius antiquus}

ao melhor resultado. Por essa razão, sustento que aqueles que agem equivocadamente não são nem sábios nem prudentes. ${ }^{79}$

O Sócrates de Xenofonte, portanto, supõe uma escolha para que se inicie a busca pela sabedoria, mas nessa passagem não explica como essa escolha se dá. Porém, no

primeiro capítulo do segundo livro dos Memoráveis, ${ }^{80}$ esse tema é desenvolvido com o auxílio de figuras míticas. O filósofo parafraseia o que ouvira do sofista Pródico sobre Hércules. Segundo ele, Pródico, quando Hércules passava da meninice para a juventude, estando em dúvida quanto a se seguiria a via do vício ou a da virtude, duas jovens apareceram diante dele, uma por natureza nobre (eleuthérion phûsei), de bela aparência, adornada com pureza, com pudor no olhar e vestida de branco, e outra excessivamente maquiada, afetada, vestida despudoradamente, vaidosa, sendo a primeira a virtude (Areté) e, a segunda, o vício (Kakía).

O que chama a atenção em primeiro lugar nessa imagem é que a escolha é feita na puberdade; em segundo lugar, é que são duas jovens, cada qual atraente a seu modo. Isso sugere que a virtude e o vício trazem em si as graças de Afrodite. Como vimos antes, a Afrodite vulgar tem rituais licenciosos, e a celeste, puros, enquanto, no trecho em questão, Areté é representada adornada com pureza, enquanto Kakía se veste de forma provocante. Podemos sugerir então que a escolha entre o vício e a virtude se daria quando o erotismo se revelasse ao ser humano (i.e. na puberdade), época em que lhe caberia escolher entre o éros celeste, o amor da alma, da amizade e das belas ações, e o éros terreno, o amor dos corpos - escolha que afetaria o restante de sua vida. Quem se deixasse guiar pelo éros terreno tomaria a via do prazer e do vício, crendo estar vivendo do melhor modo possível. Quem se deixasse guiar pelo éros celeste, por sua vez, não veria prazer na rota do vício, mas simplesmente compulsão. Outrossim, buscando em cada ato a excelência, procuraria realizar-se através do próprio esforço com dignidade, encontrando satisfação nesse esforço e colhendo os frutos de sua kalokagathía. ${ }^{81}$

\section{Conclusão}

Vimos, portanto, que o pensamento socrático segundo Xenofonte volta-se totalmente para questões existenciais e para a ação, objetivando criar um homem

\footnotetext{
${ }^{79}$ Cf. Memoráveis III 9, 4-5.

${ }^{80} \mathrm{Cf}$. Memoráveis I 2, 21-34.

${ }^{81} \mathrm{Cf}$. Memoráveis II 1, 28.
} 
integralmente forte diante das dificuldades, frugal, generoso, bom amigo e senhor de si mesmo. A via que leva o homem a esse desenvolvimento é escolhida na puberdade, quando se opta ou pelo éros terreno, que leva à servidão, ao vício e à indignidade, ou pelo éros celeste, que conduz à amizade, ao domínio de si mesmo, à liberdade e à kalokagathía.

\section{Referências}

DIELS H.; KRANZ W. Die Fragmente der Vorsokratiker griechisch und deutsch. Berlim: Weidmannsche Buchhandlung, 1903.

DIÓGENES LAÉRCIO. Vidas e doutrinas dos filósofos ilustres. Tradução de Mário da Gama Kury. Brasília: UNB, 1988.

HESÍODO. Teogonia / Os trabalhos e dias. Tradução de Ana Elias Pinheiro \& José Ribeiro Ferreira. Lisboa: Imprensa Nacional, 2005.

PLATÃO. Apology. Translated by Harold North Fowler. London: Harvard University Press, 1995.

Press, 1990.

. Eutidemus. Translated by W. R. M. Lamb. London: Harvard University

. Eutiphron. Translated by Harold North Fowler. London: Harvard University Press, 1995.

. Laches. Translated by W. R. M. Lamb. London: Harvard University Press, 1990.

1991.

Lisias. Translated by W. R. M. Lamb. London: Harvard University Press, Press, 1990.

. Protagoras. Translated. by W. R. M. Lamb. London: Harvard University

STRAUSS, L. Xenophon's Socrates. New York: Augustine Press, 1997.

XENOPHON. Anabasis. Translated by E. C. Marchant. London: Harvard University Press, 1996. 


\section{nuntius antiquus}

. Anabasis. Traducción de F. M. Oca. Madrid: Patyta, 2006.

Memorabilia; Oeconomicus; Symposium; Apology. Translated by E. C. Marchant. London: Harvard University Press, 2002.

Ciropedia. Translated by E. C. Marchant. 8 ed. London: Harvard University Press, 2005.

Ciropedia. A Educação de Ciro. Tradução de José Perez. São Paulo:

Ediouro, 2003. 